\title{
THE EFFECT OF MODIFIED ATMOSPHERE PACKAGING ON THE QUALITY AND SHELF LIFE OF FRANKFURTER TYPE-SAUSAGES
}

\author{
NALAN GOKOGLU ${ }^{1,4}$, PINAR YERLIKAYA ${ }^{1}$, HARUN URAN $^{2}$ and \\ OSMAN KADIR TOPUZ ${ }^{3}$ \\ ${ }^{1}$ Fisheries Faculty Fish Processing Department \\ Akdeniz University \\ Antalya, Turkey \\ ${ }^{2}$ School of Professional Education \\ Istanbul Aydin University \\ Istanbul, Turkey
${ }^{3}$ Engineering Faculty Food Engineering Department
Akdeniz University
Antalya, Turkey

Received for Publication May 26, 2008

Accepted for Publication January 2, 2009

\begin{abstract}
The effects of modified atmosphere packaging on the quality and shelf life of frankfurter-type sausages, prepared exclusively from beef meat, were investigated. Sausages were packed under varying modified atmosphere conditions $\left(30 \% \mathrm{CO}_{2} / 70 \% \mathrm{~N}_{2} ; 70 \% \mathrm{CO}_{2} / 30 \% \mathrm{~N}_{2} ; 100 \% \mathrm{CO}_{2} ; 80 \% \mathrm{CO}_{2} / 20 \% \mathrm{O}_{2}\right.$ ) and vacuum, and stored at $4 C$ for 28 days. Lower $\mathrm{pH}$ values were observed in the samples packed under modified atmospheres compared to vacuum. Inhibition effect of carbon dioxide concentration on the oxidation was seen. Carbon dioxide caused microbial inhibition. The lowest total viable count was found in the samples packed under $100 \% \mathrm{CO}_{2}$. It was concluded that modified atmosphere packaging had significant effect on the quality and shelf life of frankfurter-type sausages compared to vacuum packaging. The most suitable atmosphere among the tested atmospheres was that with $70 \% \mathrm{CO}_{2}, 30 \% \mathrm{~N}_{2}$ atmosphere. The shelf life of sausages under this atmosphere was 28 days.
\end{abstract}

${ }^{4}$ Corresponding author. TEL: +90-2423101974; FAX: +90-2422262013; EMAIL: ngokoglu@ akdeniz.edu.tr 


\section{PRACTICAL APPLICATIONS}

Meat and meat products are susceptible to spoilage. Several preservation techniques are used to extend their shelf life. Packaging of fresh meat is a common application to protect its quality. Modified atmosphere packaging (MAP) means to replace the air in a package of food with some different mixture of gases. The success in MAP is to choose the suitable gas combination, packaging system, package application and the package material. Proper gas combination to keep meat quality should be provided. Several studies have been performed to extent shelf life of pork sausages and local-type sausages using modified atmosphere packaging technique. However there is no data on beef sausages. The results of this research will form the basis for further studies and also will be beneficial for industry.

\section{INTRODUCTION}

Modified atmosphere packaging (MAP) means replacing the air in a package of food with a different mixture of gases, typically a combination of nitrogen and oxygen (Cann 1984).

Sausages, by definition, are prepared from the flesh of meat animals. Sausages can be produced using beef, veal, pork, chicken, turkey or lamb. Frankfurters are nonfermented, emulsion-type sausages. They are usually made from beef, lamb meat and pork, and are flavored with spices and the application of smoke. All frankfurters may contain up to $30 \%$ fat. They are cooked before service. Meat products such as frankfurters are sensitive to spoilage and are stored under vacuum or modified atmosphere. Different results have been found in the studies performed on the shelf life of cooked meat products packed under vacuum and modified atmosphere, depending on the type of the product. Some researchers reported that modified atmosphere packaging extended the shelf life of cooked meat products, whereas other researchers found no effect of packaging method on the shelf life (Boerema et al. 1993; Borch et al. 1996; Samelis and Georgiadou 2000; Metaxopoulos et al. 2002; Pexara et al. 2002). However, there are very few reports on frankfurters packed under modified atmosphere, and these reports are generally on pork sausages (Liserre et al. 2002; Metaxopoulos et al. 2002; Martinez et al. 2005, 2006) or local-type sausages (Wang et al. 1995; Santos et al. 2003, 2005; Samelis and Georgiadou 2000). There is no study with beef frankfurters.

Beef frankfurters are widely produced and consumed in Turkey. They are generally marketed in vacuum packs. Some manufacturers use modified atmosphere packaging with different gas mixtures. In this study, we aimed to 
determine quality changes and shelf life of frankfurter-type sausages packed under varying modified atmospheres and to find most suitable atmosphere to extend the shelf life of frankfurters.

\section{MATERIALS AND METHODS}

\section{Processing of Sausages}

Frankfurters were manufactured in a private meat processing plant in Antalya, Turkey. Sausages were produced by fresh boneless beef cuts from shoulder. Beef meat was trimmed of visible fat, minced through a $3 \mathrm{~mm}$ plate using a Mado mincer MEW 5102 (Domhan, Germany) and then placed in a cutter (Mado, MTK 661) along with the other ingredients. For $1 \mathrm{~kg}$ of batter, the following ingredients were used: $600 \mathrm{~g}$ beef, $322 \mathrm{~g}$ emulsion (containing $50 \%$ fat), $60 \mathrm{~g}$ water, $3.8 \mathrm{~g}$ sodium lactate, $4.8 \mathrm{~g}$ monosodium glutamate, $3 \mathrm{~g}$ nitrite salt, $4.9 \mathrm{~g}$ sodium tripolyphosphate and $2.92 \mathrm{~g}$ spice mix. Total mixing time was $10-15 \mathrm{~min}$ and the final temperature of the batter was $10.0-12.3 \mathrm{C}$. Prepared frankfurter mixture was stuffed using a vacuum stuffer (Handtmann, VF100/240, Biberach, Germany) into $14 \mathrm{~mm}$ diameter cellulose casings. The frankfurters were hanged, smoked and cooked for $25 \mathrm{~min}$ in an oven at $76 \mathrm{C}$. The cooked frankfurters were showered with cold water until their internal temperature was reduced to $16-18 \mathrm{C}$, and after showering, they were kept overnight at $4 \mathrm{C}$.

\section{Packaging}

Sausages were peeled using machine, placed on plastic foam trays and put into plastic pouches (size: $17.5 \times 13.5 \times 2.5 \mathrm{~cm}$ ). The plastic pouches were composed of polyamide $(80 \mu \mathrm{m})$ and polyethylene $(250 \mu \mathrm{m})$. The polyamide film had an oxygen transmission rate $68 \mathrm{~mL} / \mathrm{m}^{2}$ day-atmosphere at $10 \mathrm{C}, 23.08 \mathrm{~mL} / \mathrm{m}^{2}$ day-atmosphere at $25 \mathrm{C}$ and water vapor permeability of $1.37 \mathrm{~mL} / \mathrm{m}^{2}$ at $37.8 \mathrm{C}$. Frankfurters were packed under vacuum and (V) under modified atmospheres with the following gas mixtures: (A) $30 \% \mathrm{CO}_{2} /$ $70 \% \mathrm{~N}_{2}$; (B) $70 \% \mathrm{CO}_{2} / 30 \% \mathrm{~N}_{2}$; (C) $100 \% \mathrm{CO}_{2}$; (D) $80 \% \mathrm{CO}_{2} / 20 \% \mathrm{O}_{2}$. The packages were gas flushed and sealed using a MULTIVAC packaging machine (R230/719, Multivac, Wolfertschwenden, Germany). The meat to gas volume ratio was 1/1 (Moller et al. 2003; Rubio et al. 2007). Packed sausages were stored at $4 \mathrm{C}$ and assessed for $\mathrm{pH}$, thiobarbituric acid (TBA), color, microbiological counts and sensory attributes on the 7th, 14th, 21st and 28th day of storage. The experiment was repeated with samples produced and packaged at two separate times. For chemical and microbiological analysis, sausages were homogenized using a kitchen blender, the homoge- 
nates were pooled for each treatment. All assays were conducted on duplicate samples from the homogenate pool for each replication. Results were expressed as means of four duplicates.

\section{Analysis}

pH Measurement. The $\mathrm{pH}$ was measured using a pH-meter (WTW Inolab, Weilhem, Germany). The $\mathrm{pH}$ electrode was dipped into a mixture of homogenized sample and distilled water (1/1).

TBA Analysis. The TBA distillation method was performed as described by Tarladgis et al. (1960). A homogenized $10 \mathrm{~g}$ sample was distilled after the addition of $2.5 \mathrm{~mL} \mathrm{HCl}+$ distilled water solution (1/2). A $5 \mathrm{~mL}$ of distilled solution was transferred into the stoppered test tube and $5 \mathrm{~mL}$ TBA solution ( $0.288 \mathrm{~g}$ TBA$/ 100 \mathrm{~mL}$ distilled water) was added, the test tube was shaken and left in the water bath at $110 \mathrm{C}$ for $35 \mathrm{~min}$. The absorbance was determined by a spectrophotometer at $538 \mathrm{~nm}$ against a blank containing distilled water and TBA solution. The results were expressed as $\mathrm{mg}$ malonaldehyde $/ \mathrm{kg}$.

Color Measurement. A CR-400 Minolta chroma meter (Minolta, Osaka, Japan) instrument was used to measure the color of frankfurters after manufacture. Three readings on the surface of frankfurters were taken using the CIE Laboratory $L^{*}$ (lightness), $a^{*}$ (redness), $b^{*}$ (yellowness) system in day light conditions.

Microbiological Analysis. For microbiological analysis, a $25 \mathrm{~g}$ sample was added to $225 \mathrm{~mL}$ of sterile $0.1 \%$ (w/v) saline peptone water $(0.1 \%$ peptone and $0.85 \% \mathrm{NaCl}$ ) and homogenized in a stomacher (Stomacher 80, Seward Medical, London, UK) for 2 min at low speed at room temperature. Serial decimal dilutions were made and plated onto appropriate culture media. Aerobic mesophilic counts (APC) were determined using Agar (PCA - Oxoid CM0463B) (35C for $48 \mathrm{~h}$ under aerobic conditions). Lactic acid bacteria (LAB) were determined on All Purpose Agar with Tween 80-Acumedia 7302 ( $25 \mathrm{C}$ for $72 \mathrm{~h}$ in an anaerobic jar). The colonies from selected dilutions were enumerated as colony forming units.

Sensory Analysis. Five experienced panelists, staff members of the Department of Food Engineering, who had experience on meat products were chosen to evaluate the quality of sausages. Before presentation to the panel, the samples were coded using letters and randomly presented to the panelists. Panelists were asked to evaluate the appearance, color and odor of samples. Appearance and color were evaluated in unopened packages; odor was evalu- 
ated just after opening the packages. Appearance, color and odor were scored on a 5 -point hedonic scale as follows: $5=$ excellent, $4=$ good, $3=$ acceptable, $2=$ fair and $1=$ unacceptable (Kotzekidou and Bloukas 1996). An overall quality score was calculated as the mean score of appearance, color and odor.

\section{Statistical Analysis}

Data were analyzed by a split plot design in a completely randomized system, with treatments as a whole plot and storage time and treatments by storage time as a sub-plot (Gomez and Gomez 1985). Means were compared using Duncan's multiple range test. Data analyses were performed using SAS.

\section{RESULTS AND DISCUSSION}

There were differences in $\mathrm{pH}$ between vacuum packaging and MAP (Table 1). Lower $\mathrm{pH}$ values were observed in samples packed under modified atmospheres when compared with vacuum. The mean initial $\mathrm{pH}$ of sausages before packaging was 6.41 and significantly decreased at day 14 in samples packed under $30 \% \mathrm{CO}_{2} / 70 \% \mathrm{~N}_{2}, 70 \% \mathrm{CO}_{2} / 30 \% \mathrm{~N}_{2}$ and $100 \% \mathrm{CO}_{2}$ atmospheres (Fig. 1). It is assumed that increase in LAB count of these samples after 14th day cause decrease in $\mathrm{pH}$. The decrease in $\mathrm{pH}$ was rapid in samples packed under $70 \% \mathrm{CO}_{2} / 30 \% \mathrm{~N}_{2}$ and $100 \% \mathrm{CO}_{2}$ atmospheres. There were no significant differences in $\mathrm{pH}$ of samples packed under $80 \% \quad \mathrm{CO}_{2} / 20 \% \quad \mathrm{O}_{2}$ atmosphere between storage days. There were significant differences $(P<0.01)$ in $\mathrm{pH}$ among the atmospheres during the storage. The decrease was related to the concentration of carbon dioxide. Lower $\mathrm{pH}$ values were found with higher carbon dioxide concentrations for pork sausages (Martinez et al. 2005) and pork meat (Juncher et al. 2001; Jakobsen and Bertelsen 2004). The reason of this effect for carbon dioxide on the $\mathrm{pH}$ can be explained by absorption of carbon dioxide by meat and formation of carbonic acid.

The TBA values of samples packed under $30 \% \mathrm{CO}_{2} / 70 \% \mathrm{~N}_{2}, 70 \% \mathrm{CO}_{2} /$ $30 \% \mathrm{~N}_{2}$ and $100 \% \mathrm{CO}_{2}$ atmospheres increased in 7 days and then decreased $(P<0.01)$ until the end of storage. Whereas TBA values of samples packed under $80 \% \mathrm{CO}_{2} / 20 \% \mathrm{O}_{2}$ atmosphere increased up to 21 days and decreased at the end of storage (Fig. 2). There were no significant differences in the TBA values of samples packed under vacuum during the storage. At the end of storage, the TBA values of the samples were higher than the initial values. This result indicated rancidity development during the storage. It is stated that sausages are susceptible to oxidation compared to whole muscle, because reduction in particle size, by grinding, disrupted membranes cause to incorporation of air and oxygen into the tissues (Martinez et al. 2006). According to 
TABLE 1.

EFFECT OF PACKAGING METHODS AND STORAGE TIME ON PHYSICOCHEMICAL, MICROBIOLOGICAL AND SENSORY PARAMETERS OF FRANKFURTER TYPE SAUSAGES*

\begin{tabular}{lllllllll}
\hline Factors & \multicolumn{7}{l}{ Parameters } \\
\cline { 2 - 8 } & $\mathrm{pH}$ & $\mathrm{TBA} \dagger$ & $L^{*}$ & $a^{*}$ & $b^{*}$ & TVC $\neq$ & LAB $^{3}$ & Sensory \\
\hline Packaging methods $\S$ & & & & & & & & \\
A & $6.38^{\mathrm{x}}$ & $0.56^{\mathrm{x}}$ & $49.97^{\mathrm{x}}$ & $26.17^{\mathrm{x}}$ & $13.08^{\mathrm{x}}$ & $5.46^{\mathrm{x}}$ & $5.33^{\mathrm{x}}$ & $4.12^{\mathrm{x}}$ \\
$\mathrm{B}$ & $6.36^{\mathrm{y}}$ & $0.34^{\mathrm{xy}}$ & $49.71^{\mathrm{x}}$ & $26.30^{\mathrm{x}}$ & $13.11^{\mathrm{x}}$ & $4.49^{\mathrm{x}}$ & $4.09^{\mathrm{x}}$ & $4.5^{\mathrm{x}}$ \\
$\mathrm{C}$ & $6.36^{\mathrm{y}}$ & $0.30^{\mathrm{y}}$ & $48.69^{\mathrm{x}}$ & $25.77^{\mathrm{xy}}$ & $13.11^{\mathrm{x}}$ & $4.26^{\mathrm{x}}$ & $4.29^{\mathrm{x}}$ & $4.10^{\mathrm{x}}$ \\
$\mathrm{D}$ & $6.38^{\mathrm{y}}$ & $0.30^{\mathrm{y}}$ & $51.23^{\mathrm{x}}$ & $24.78^{\mathrm{y}}$ & $13.70^{\mathrm{x}}$ & $4.46^{\mathrm{x}}$ & $3.52^{\mathrm{x}}$ & $3.84^{\mathrm{x}}$ \\
V & $6.47^{\mathrm{x}}$ & $0.23^{\mathrm{y}}$ & $51.31^{\mathrm{x}}$ & $25.21^{\mathrm{xy}}$ & $13.97^{\mathrm{x}}$ & $4.97^{\mathrm{x}}$ & $4.48^{\mathrm{x}}$ & $3.54^{\mathrm{x}}$ \\
Standard error & 0.012 & 0.04 & 0.49 & 0.19 & 0.026 & 0.2 & 0.27 & 0.16 \\
Storage time (d)II & & & & & & & & \\
0 & $6.41^{\mathrm{x}}$ & $0.13^{\mathrm{x}}$ & $48.85^{\mathrm{x}}$ & $26.19^{\mathrm{x}}$ & $13.38^{\mathrm{x}}$ & $3.89^{\mathrm{x}}$ & $3.58^{\mathrm{x}}$ & $5.0^{\mathrm{x}}$ \\
7 & $6.38^{\mathrm{x}}$ & $0.44^{\mathrm{y}}$ & $49.23^{\mathrm{x}}$ & $24.98^{\mathrm{x}}$ & $12.83^{\mathrm{x}}$ & $4.07^{\mathrm{x}}$ & $3.92^{\mathrm{x}}$ & $4.46^{\mathrm{xy}}$ \\
14 & $6.34^{\mathrm{x}}$ & $0.40^{\mathrm{y}}$ & $49.23^{\mathrm{x}}$ & $25.23^{\mathrm{x}}$ & $12.83^{\mathrm{x}}$ & $4.61^{\mathrm{xy}}$ & $4.18^{\mathrm{x}}$ & $4.02^{\mathrm{yz}}$ \\
28 & $6.40^{\mathrm{x}}$ & $0.42^{\mathrm{y}}$ & $50.33^{\mathrm{x}}$ & $25.83^{\mathrm{x}}$ & $12.83^{\mathrm{x}}$ & $5.36^{\mathrm{y}}$ & $4.72^{\mathrm{x}}$ & $3.72^{\mathrm{z}}$ \\
Standard error & $6.41^{\mathrm{x}}$ & $0.33^{\mathrm{xy}}$ & $53.28^{\mathrm{y}}$ & $25.99^{\mathrm{x}}$ & $15.11^{\mathrm{y}}$ & $5.71^{\mathrm{y}}$ & $5.31^{\mathrm{x}}$ & $2.90^{\mathrm{q}}$ \\
\hline
\end{tabular}

* Means within the same factor and the same column with different superscript letters $(\mathrm{x}, \mathrm{y}, \mathrm{z}, \mathrm{q})$ are different $(P<0.05)$.

$\dagger \mathrm{mg}$ malonaldehyde/kg.

$\ddagger \log _{10} \mathrm{cfu} / \mathrm{g}$.

$\S$ Each number represents the average value of each parameter for all samples of the same treatment. $\mathrm{A}=30 \% \mathrm{CO}_{2} / 70 \% \mathrm{~N}_{2} ; \mathrm{B}=70 \% \mathrm{CO}_{2} / 30 \% \mathrm{~N}_{2} ; \mathrm{C}=100 \% \mathrm{CO}_{2} ; \mathrm{D}=80 \% \mathrm{CO}_{2} / 20 \% \mathrm{O}_{2} ; \mathrm{V}=$ vacuum.

II Each number represents the average value of each parameter for all samples with the same storage time.

results of TBA analysis, inhibition effect of carbon dioxide concentration on the oxidation was seen at concentrations of $\mathrm{CO}_{2}>70 \%$. The increase in concentration of carbon dioxide caused inhibition. Our samples packed under modified atmosphere had higher TBA values than those packed under vacuum. While similar findings were reported by some researchers (Kerry et al. 2000; Berruga et al. 2005; Martinez et al. 2006), others found less oxidation in modified-atmosphere packed samples than those in vacuum packed (Wang et al. 1995).

Color of meat is an important quality attribute that influences consumer acceptance of meat and meat products (Glitsch 2000). High oxygen concentrations enhance bright-red color to fresh meat, but low concentration accelerates the oxidation of myoglobin to metmyoglobin which turns the color to brown. However, in meat products which are produced with nitrites the red cured color is rapidly turns to brown when oxygen and light are present. There were no significant differences in $L^{*}$ values of samples in all packages in 14 
$\mathrm{pH}$

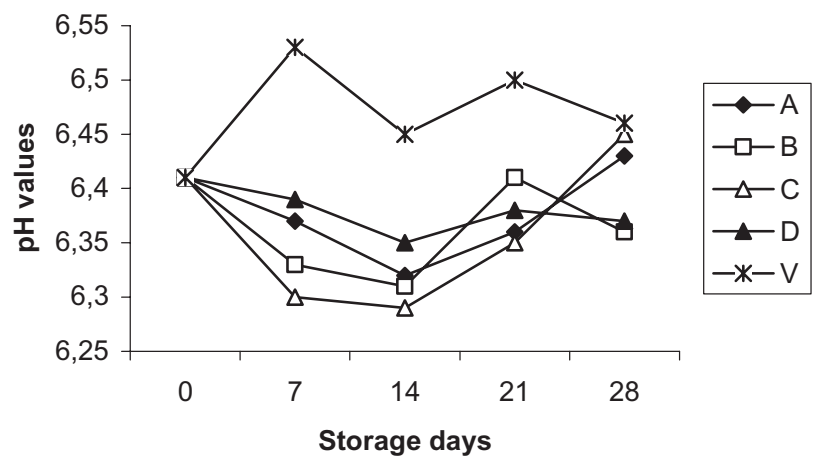

$\mathrm{A}=30 \% \mathrm{CO}_{2} / 70 \% \mathrm{~N}_{2} ; \mathrm{B}=70 \% \mathrm{CO}_{2} / 30 \% \mathrm{~N}_{2} ; \mathrm{C}=100 \% \mathrm{CO}_{2} ; \mathrm{D}=80 \% \mathrm{CO}_{2} / 20 \% \mathrm{O}_{2} ; \mathrm{V}=$ vacuum

FIG. 1. $\mathrm{pH}$ VALUES OF SAUSAGES PACKED UNDER MODIFIED ATMOSPHERE AND VACUUM DURING THE STORAGE AT 4C

\section{TBA}

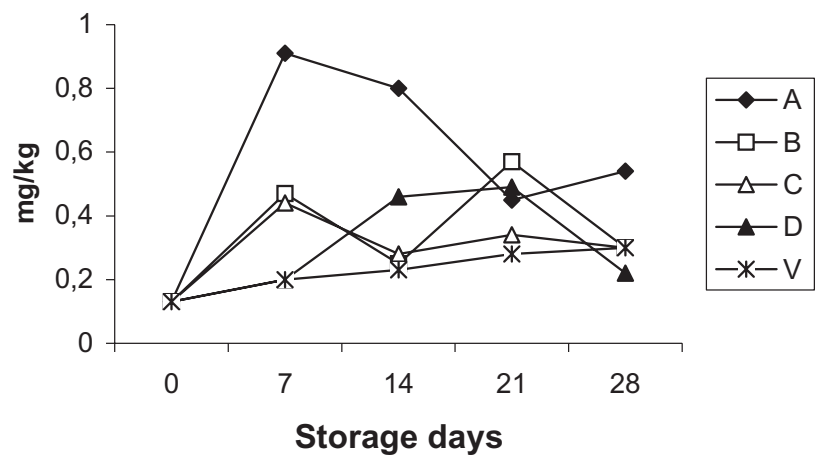

$\mathrm{A}=30 \% \mathrm{CO}_{2} / 70 \% \mathrm{~N}_{2} ; \mathrm{B}=70 \% \mathrm{CO}_{2} / 30 \% \mathrm{~N}_{2} ; \mathrm{C}=100 \% \mathrm{CO}_{2} ; \mathrm{D}=80 \% \mathrm{CO}_{2} / 20 \% \mathrm{O}_{2} ; \mathrm{V}=$ vacuum

FIG. 2. THIOBARBUTIRIC ACID (TBA) VALUES OF SAUSAGES PACKED UNDER MODIFIED ATMOSPHERE AND VACUUM DURING THE STORAGE AT 4C

days. $L^{*}$ values increased after 14 days (Fig. 3). The highest value was detected in samples packed under $80 \% \mathrm{CO}_{2} / 20 \% \mathrm{O}_{2}$ atmosphere and vacuum at the end of storage. Lower values were found in samples packed under $30 \%$ $\mathrm{CO}_{2} / 70 \% \mathrm{~N}_{2}$ and $100 \% \mathrm{CO}_{2}$ atmospheres during the storage compared to the 


\section{$L$ value}

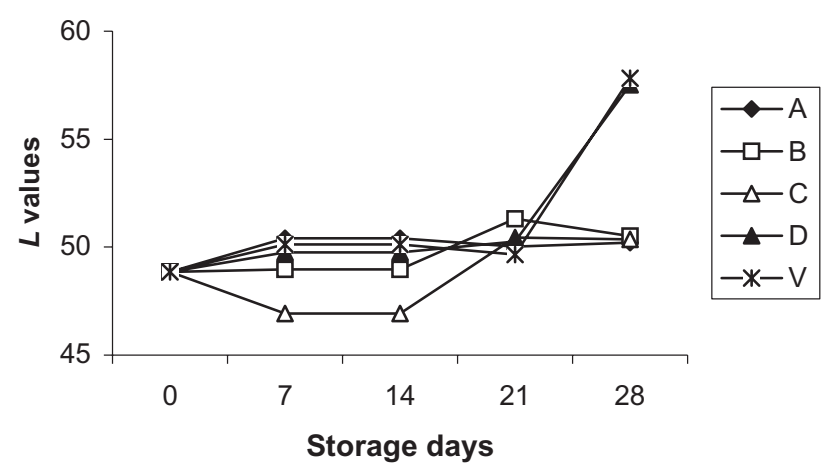

$\mathrm{A}=30 \% \mathrm{CO}_{2} / 70 \% \mathrm{~N}_{2} ; \mathrm{B}=70 \% \mathrm{CO}_{2} / 30 \% \mathrm{~N}_{2} ; \mathrm{C}=100 \% \mathrm{CO}_{2} ; \mathrm{D}=80 \% \mathrm{CO}_{2} / 20 \% \mathrm{O}_{2} ; \mathrm{V}=$ vacuum

FIG. 3. LIGHTNESS ( $\left.L^{*}\right)$ VALUES OF SAUSAGES PACKED UNDER MODIFIED ATMOSPHERE AND VACUUM DURING THE STORAGE AT 4C

other groups. There were no differences in $a^{*}$ values of samples packed under $30 \% \mathrm{CO}_{2} / 70 \% \mathrm{~N}_{2}, 70 \% \mathrm{CO}_{2} / 30 \% \mathrm{~N}_{2}$ and $100 \% \mathrm{CO}_{2}$ atmospheres throughout storage. Values of samples packed under $80 \% \mathrm{CO}_{2} / 20 \% \mathrm{O}_{2}$ atmosphere and vacuum decreased up to 21 days, then increased and reached initial values (Fig. 4). Lower values were found in samples packed under $80 \% \mathrm{CO}_{2} / 20 \% \mathrm{O}_{2}$ atmosphere than other groups. It has been demonstrated that low concentrations of oxygen in the package are responsible for color fading (Jakobsen and Bertelsen 2000). During storage, the $b^{*}$ values of samples packed under modified atmosphere and vacuum decreased (Fig. 5).

Total viable count of all the samples increased during storage (Fig. 6). The highest count was found in samples packed under the $30 \% \mathrm{CO}_{2} / 70 \% \mathrm{~N}_{2}$ atmosphere. Final total viable count of the samples packed under $30 \% \mathrm{CO}_{2} /$ $70 \% \mathrm{~N}_{2}$ atmosphere reached $7.58 \mathrm{log} \mathrm{cfu} / \mathrm{g}$. It is stated that spoilage occurs when total aerobic count reach $10^{7} \mathrm{cfu} / \mathrm{g}$ (ICMSF 1984). Other samples did not reach this level throughout storage. Vacuum packed samples had higher TVC than those packed under modified atmospheres except A atmosphere $(30 \%$ $\mathrm{CO}_{2} / 70 \% \mathrm{~N}_{2}$ ). The lowest count was found in samples packed under $100 \%$ $\mathrm{CO}_{2}$. This result showed that carbon dioxide caused microbial inhibition, but it has been stated that a concentration of 20-30\% was sufficient to prevent growth of aerobic spoilage bacteria (Sorheim et al. 2004) and high concentration of carbon dioxide was pro-oxidant causing loss of color (Jakobsen and Bertelsen 2002). 


\section{a value}

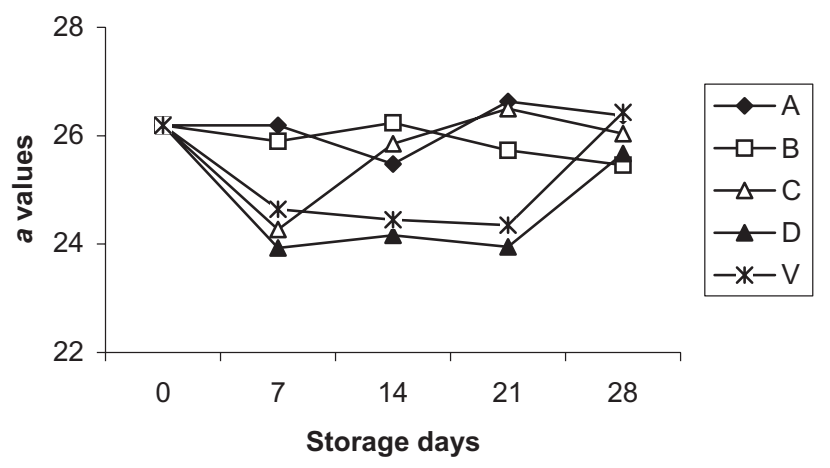

$\mathrm{A}=30 \% \mathrm{CO}_{2} / 70 \% \mathrm{~N}_{2} ; \mathrm{B}=70 \% \mathrm{CO}_{2} / 30 \% \mathrm{~N}_{2} ; \mathrm{C}=100 \% \mathrm{CO}_{2} ; \mathrm{D}=80 \% \mathrm{CO}_{2} / 20 \% \mathrm{O}_{2} ; \mathrm{V}=$ vacuum

FIG. 4. REDNESS $\left(a^{*}\right)$ VALUES OF SAUSAGES PACKED UNDER MODIFIED ATMOSPHERE AND VACUUM DURING THE STORAGE AT 4C

\section{$b$ value}

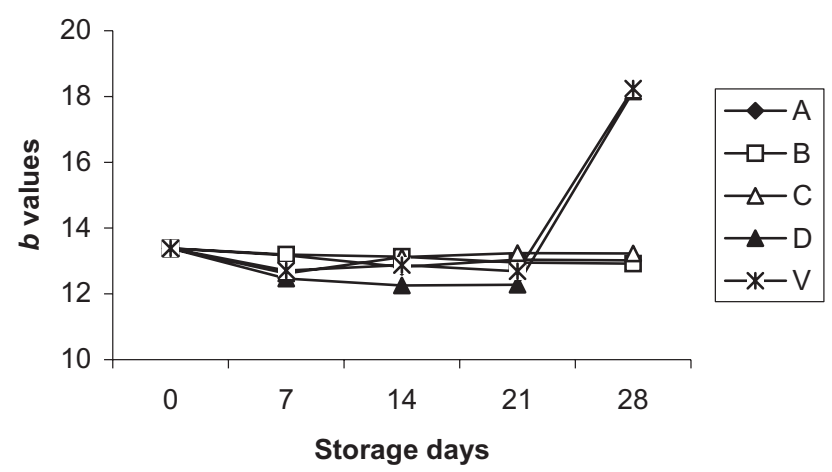

$\mathrm{A}=30 \% \mathrm{CO}_{2} / 70 \% \mathrm{~N}_{2} ; \mathrm{B}=70 \% \mathrm{CO}_{2} / 30 \% \mathrm{~N}_{2} ; \mathrm{C}=100 \% \mathrm{CO}_{2} ; \mathrm{D}=80 \% \mathrm{CO}_{2} / 20 \% \mathrm{O}_{2} ; \mathrm{V}=$ vacuum

FIG. 5. YELLOWNESS $\left(b^{*}\right)$ VALUES OF SAUSAGES PACKED UNDER MODIFIED ATMOSPHERE AND VACUUM DURING THE STORAGE AT 4C 


\section{TVC}

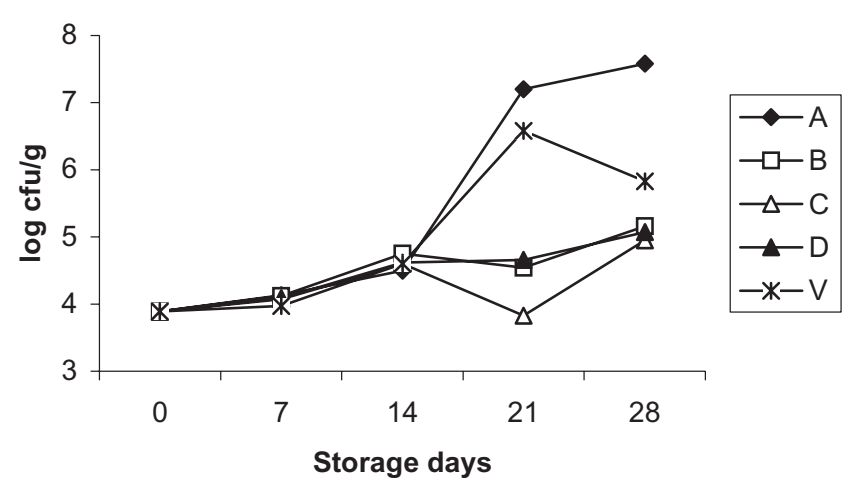

$\mathrm{A}=30 \% \mathrm{CO}_{2} / 70 \% \mathrm{~N}_{2} ; \mathrm{B}=70 \% \mathrm{CO}_{2} / 30 \% \mathrm{~N}_{2} ; \mathrm{C}=100 \% \mathrm{CO}_{2} ; \mathrm{D}=80 \% \mathrm{CO}_{2} / 20 \% \mathrm{O}_{2} ; \mathrm{V}=$ vacuum

FIG. 6. TOTAL VIABLE COUNT (TVC) OF SAUSAGES PACKED UNDER MODIFIED ATMOSPHERE AND VACUUM DURING THE STORAGE AT 4C

When bacterial flora of such meats is examined it is commonly found that lactic acid bacteria are a major component (Kitchell and Shaw 1975). Vacuum packed cooked meats such as emulsion type sausages are more susceptible to spoilage, due to their $\mathrm{pH}$ and water activity values and require refrigeration for an adequate shelf life. Heterofermentative lactic acid bacteria cause spoilage of these products. Spoilage of cured meats by lactic acid bacteria is characterized by sour off-flavor (Egan 1983), discoloration, gas formation, slime production and low $\mathrm{pH}$ (Borch et al. 1996; Pexara et al. 2002). The count of lactic acid bacteria of samples packed under $30 \% \mathrm{CO}_{2} / 70 \% \mathrm{~N}_{2}, 70 \% \mathrm{CO}_{2} / 30 \%$ $\mathrm{N}_{2}$ and $100 \% \mathrm{CO}_{2}$ atmospheres and vacuum increased during the storage (Fig. 7). The removal of oxygen from their packaging creates an environment which is favorable for these bacteria. The count in samples packed under $80 \%$ $\mathrm{CO}_{2} / 20 \% \mathrm{O}_{2}$ atmosphere increased in 14 days and decreased after 14 days. The lowest count was found for samples packed under $80 \% \mathrm{CO}_{2} / 20 \% \mathrm{O}_{2}$ atmosphere at the end of storage. This result was in agreement with Santos et al. (2005). At the end of storage lactic acid bacteria count of the samples packed under $30 \% \mathrm{CO}_{2} / 70 \% \mathrm{~N}_{2}$ atmosphere reached $8.31 \log \mathrm{cfu} / \mathrm{g}$. This is over the limit values given by ICMSF (1984). The rate of carbon dioxide in the gas mixture affected the growth of lactic acid bacteria. Higher inhibition effect was observed when the gas mixture contained over $30 \% \mathrm{CO}_{2}$. Similar results have been given in the previous studies (Blickstad and Molin 1984; Borch et al. 1996; Metaxopoulos et al. 2002). On the contrary, some researchers have 


\section{LAB}

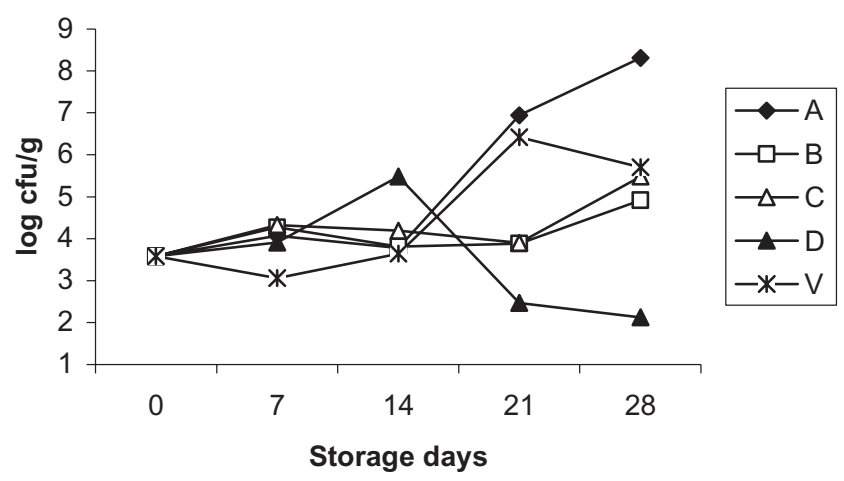

$\mathrm{A}=30 \% \mathrm{CO}_{2} / 70 \% \mathrm{~N}_{2} ; \mathrm{B}=70 \% \mathrm{CO}_{2} / 30 \% \mathrm{~N}_{2} ; \mathrm{C}=100 \% \mathrm{CO}_{2} ; \mathrm{D}=80 \% \mathrm{CO}_{2} / 20 \% \mathrm{O}_{2} ; \mathrm{V}=$ vacuum

FIG. 7. LACTIC ACID BACTERIA (LAB) COUNT OF SAUSAGES PACKED UNDER MODIFIED ATMOSPHERE AND VACUUM DURING THE STORAGE AT 4C

reported that modified atmosphere packaging did not indicate retarding effect on the growth rate of lactic acid bacteria compared to vacuum packaging (Korkeala et al. 1991; Samelis and Georgiadou 2000; Pexara et al. 2002; Kant-Muermans et al. 1997).

Sensory scores of sausages packed under modified atmospheres and vacuum decreased during the storage (Fig. 5). Lower scores were observed in samples packed under vacuum than those packed under modified atmospheres. Comparing packaging under modified atmosphere and under vacuum, it was found that modified atmosphere packaging had significant effect on sensory quality of the samples. Atmosphere $80 \% \mathrm{CO}_{2} / 20 \% \mathrm{O}_{2}$ had the lowest sensory scores compared to the other packs with modified atmosphere. The best sensory quality among all the tested packaging methods were obtained for $70 \% \mathrm{CO}_{2} / 30 \% \mathrm{~N}_{2}$ atmosphere, throughout the storage period. The shelf life of frankfurters in this treatment was more than 28 days at $4 \mathrm{C}$.

\section{CONCLUSION}

Sausages are susceptible to spoilage and, so far, vacuum packaging was the most widely used packaging technique for sausages. In this research, it was found that MAP was more effective in improving the quality and shelf life of 
frankfurter-type sausages than vacuum packaging. Four different gas mixtures were studied and found that concentration of carbon dioxide in the pack was effective to inhibit microbial growth and fat oxidation. High concentration of carbon dioxide also caused decrease in the $\mathrm{pH}$ value of sausages. The presence of oxygen in the pack resulted in pale color and lower sensory scores. For this reason, oxygen should not be used in the package of frankfurter sausages. Atmosphere containing $70 \% \mathrm{CO}_{2}, 30 \% \mathrm{~N}_{2}$ was the most appropriate atmosphere to keep quality and extend the shelf life of sausages.

\section{ACKNOWLEDGMENTS}

The Scientific Research Projects Administration Unit of Akdeniz University under project no. 2003.01.04.003 supported this research. The authors would like to thank Güney Gida A.Ş. (Antalya, Turkey) for manufacturing and packaging of sausages and Mr. Ibrahim Uğurgün, factory manager, for his helps.

\section{REFERENCES}

BERRUGA, M.I., VERGARA, H. and GALLEGO, L. 2005. Influence of packaging conditions of microbial and lipid oxidation in lamb meat. Small Rum. Res. 57, 257-264.

BLICKSTAD, E. and MOLIN, G. 1984. Growth and end-product formation in fermenter cultures of Brochothrix thermosphacta ATTC11509 and two psycrotrophic Lactobacillus sp. in different gaseous atmospheres. J. Appl. Bacteriol. 57, 213-220.

BOEREMA, J.A., PENNY, N., CUMMINGS, T.L. and BELL, R.G. 1993. Controlled atmosphere packaging of sliced ham. Int. J. Food Sci. Technol. 28, 435-442.

BORCH, E., KANT-MUERMANS, M.L. and BLIXT, Y. 1996. Bacterial spoilage of meat and cured meat products. Int. J. Food Microbiol. 33, 103-120.

CANN, D.C. 1984. Packaging fish in a modified atmosphere. Torry Advisory Note No:88. Ministry of Agriculture, Fisheries and Food, Torry Research Station, Aberdeen, Scotland.

EGAN, A.F. 1983. Lactic acid bacteria of meat and meat products. Antonie von Leeuwenhoek 49, 327-336.

GLITSCH, K. 2000. Consumer perceptions of fresh meat quality: Crossnational comparison. Br. Food J. 102, 177-194.

GOMEZ, K.A. and GOMEZ, A.A. 1985. Statistical Procedures for Agricultural Research, 2nd Ed., John Wiley and Sons, New York. 
ICMSF. 1984. Microorganismos indicadore. In Microorganismos de los Alimentos. 1. Tecnicas de Analisis Microbiologico, Zaragoza, Spain.

JAKOBSEN, M. and BERTELSEN, G. 2000. Color stability and lipid oxidation of fresh beef. Development of a response surface model for predicting the effects of temperature, storage time and modified atmosphere composition. Meat. Sci. 55, 49-57.

JAKOBSEN, M. and BERTELSEN, G. 2002. The use of $\mathrm{CO}_{2}$ in packaging of fresh red meats and its effect of chemical quality changes in the meat. A review. J. Muscle Foods 13, 143-168.

JAKOBSEN, M. and BERTELSEN, G. 2004. Predicting the amount of carbon dioxide absorbed in meat. Meat Sci. 68, 603-610.

JUNCHER, D., RONN, B., MORTENSEN, E.T., HENCKEL, P., KARLSSON, A. and SKIBSTED, L.H. 2001. Effects of pre-slaughter physiological conditions on the oxidative stability of color and lipid oxidation during chill storage of pork. Meat Sci. 58, 347-357.

KANT-MUERMANS, M.L.T., STEKELENBURG, F.K., ZWIETERING, M.H. and HUIS IN'T VELD, J.H.J. 1997. Modeling the Shelf-life of Packed, Cooked Meat Products. World Congress on Food Hygiene, The Hague, pp. 53-57.

KERRY, J.P., Q'SULLIVAN, M.G., BUCKLEY, D.J., LYNCH, P.B. and MORRISSEY, P.A. 2000. The effects of dietary a-tocopheryl acetate supplementation and modified atmosphere packaging (MAP) on the quality of lamb patties. Meat Sci. 56, 61-66.

KITCHELL, A.G. and SHAW, B.G. 1975. Lactic acid bacteria in fresh and cured meat. In Lactic Acid Bacteria in Beverages and Foods (J.G. Carr, C.V. Cutting and G.C. Whiting, eds.) pp. 209-220, Fourth Long Ashton Symposium, 1973, Academic Press, London.

KORKEALA, H., RAHKIO, M., RIDELL, J. and MÄKELÄ, P. 1991. Effect of carbon dioxide packaging on ropiness observed in meat products. In Proceedings of the 37th International Congress of Meat Science and Technology 2, 4:12, pp. 571-574, Federal Center for Meat Research, Kulmbach, Germany.

KOTZEKIDOU, P. and BLOUKAS, J.G. 1996. Effects of protective cultures and packaging film permeability on shelf life of sliced vacuum-packed cooked ham. Meat Sci. 42, 333-345.

LISERRE, A.M., LANDGRAF, M., DESTRO, M.T. and FRANCO, B.D.G. 2002. Inhibition of Listeria monocytogenes by a bacteriocinogenic Lactobacillus sake strain in modified atmosphere-packaged Brazilian sausage. Meat Sci. 61, 449-455.

MARTINEZ, L., DJENANE, D., CILLA, I., BELTRAN, J.A. and RONCALES, P. 2005. Effects of different concentrations of carbon dioxide and low concentrations of carbon monoxide on the shelf life of 
fresh pork sausages packed in modified atmosphere. Meat Sci. 71, 563570.

MARTINEZ, L., DJENANE, D., CILLA, I., BELTRAN, J.A. and RONCALES, P. 2006. Effects of varying oxygen concentrations on the shelf life of fresh pork-sausages packed in modified atmosphere. Food Chem. 94, 219-225.

METAXOPOULOS, J., MATARAGAS, M. and DROSINOS, E.H. 2002. Microbial interaction in cooked cured meat products under vacuum or modified atmosphere at 4C. J. Appl. Microbiol. 93, 363-373.

MOLLER, J.K.S., JAKOBSEN, M., WEBER, C.J., MARTINUSSEN, T., SKIBSTED, L.H. and BERTELSEN, G. 2003. Optimisation of colour stability of cured ham during packaging and retail display by a multifactorial design. Meat Sci. 63, 169-175.

PEXARA, E.S., METAXOPOULOS, J. and DROSINOS, E.H. 2002. Evaluation of shelf life of cured, cooked, sliced turkey fillets and cooked pork sausages "piroski" stored under vacuum and modified atmosphere at 4 and 10C. Meat Sci. 62(1), 33-43.

RUBIO, B., MARTINEZ, B., GONZALEZ-FERNANDEZ, C., GARCIACACHAN, M.D., ROVIRA, J. and JAIME, I. 2007. Effect of modified atmosphere packaging on the microbiological and sensory quality and a dry cured beef product: "Cecina de lweon". Meat Sci. 75, 515-522.

SAMELIS, J. and GEORGIADOU, K.G. 2000. The microbial association of Greek taverna sausage stored at 4 and 10C in air, vacuum or $100 \%$ carbon dioxide and its spoilage potential. J. Appl. Microbiol. 88, 58-68.

SANTOS, E.M., GONZALEZ-FERNANDEZ, C., JAIME, I. and ROVIRA, J. 2003. Physicochemical and sensory characterization of Morcilla de Burgos, a traditional Spanish blood sausage. Meat Sci. 65, 893-898.

SANTOS, E.M., DIEZ, A.M., GONZALEZ-FERNANDEZ, C., JAIME, I. and ROVIRA, J. 2005. Microbiological and sensory changes in "Morcilla de Burgos" preserved in air vacuum and modified atmosphere packaging. Meat Sci. 71, 249-255.

SORHEIM, O., OFSTAD, R. and LEA, P. 2004. Effects of carbon dioxide on yield, texture and microstructure of cooked ground beef. Meat Sci. 67, 231-236.

TARLADGIS, B.G., WATTS, B.M. and YOUNATHAN, M.T. 1960. A distillation method for the quantitative determination of malonaldehyde in rancid foods. J. Am. Oil Chem. Soc. 37, 44-48.

WANG, F.S., JIANG, Y.N. and LIN, C.W. 1995. Lipid and cholesterol oxidation in Chinese-style sausage using vacuum and modified atmosphere packaging. Meat Sci. 40, 93-101. 